\title{
An analysis of audit fee premiums of the merged audit firm in Malaysia
}

\begin{abstract}
After the Big 6 merger exercise in 1998, PriceWaterhouseCoopers (PWC) has become the industry market leader that provides high quality audit services. Consequently, it has acquired a greater capacity to develop expertise and provide better quality audit services. It is expected that PWC charges fee premiums in return on investment for the capacity building. This study investigates how audit fee (AF) premiums and how it relates to auditors' industry specialisation and reputation. The study utilises data of 679 Bursa Malaysia listed companies in 2001 and 796 in 2005. AF premiums are calculated using the Simunic (1980) AF model. Industry specialisation is determined based on the number of audit clients at $20 \%$ threshold. Results indicate PWC obtains highest average AFs, hence, maintains its industry leadership. Results show that PWC does not charge AF premiums over and above the amount charged by the Big 5/4 regardless of whether they are industry specialists or not, except on smaller clients.
\end{abstract}

Keyword: Industry specialisation; Audit fee premiums; Audit reputation; Audit industry leadership 